\title{
Indonesia Master of Education Student's Perceptions of Their Experience in Learning Tesol in the Tertiary Context in Australia
}

\author{
Neni Djafar \\ nhenybhono@gmail.com \\ SMP Negeri 1 Kabupaten Sorong \\ Jl.Klamono Km 19 Aimas. Kabupaten Sorong
}

\begin{abstract}
The aim of research study is to investigate the manner how experience in learning TESOL in tertiary context in Australia impacts on Indonesian M.Ed Students' perception in the English language learning and in the English language teaching in their context. Although there have been many studies conducted with regard to the perceptions of international students with non-English backgrounds from Asian countries, there is no specific study yet conducted pertaining to how experience in learning TESOL in tertiary context in Australia impacts on Indonesian M.Ed Students' perception in the English language learning and in the English language teaching in their context. The method used to collect data from the participants of the study consisting of eight of them is an individual semi-structured interview with openended questions and descriptive thematic analysis to analyze the data to generate the result of the study.
\end{abstract}

Keywords: $\quad$ Experience in learning TESOL, Tertiary Context in Australia, Indonesian M. Ed students and Perception

\section{Introduction}

In recent years, an array of research has been conducted on the subject of studying experiences for international students from Asian background in tertiary education in native speaking countries like Australia (see, Andrade, 2006, 2010 \& Australian Education International (AEI), 2013 as cited in (Phakiti, Hirsh \& Woodrow 2013). It is true that studying overseas, they should be knowledgeable in their field of study and mastering English simultaneously as the most predetermining prerequisite. Because it is stated that to be accepted at tertiary education context in Australia their English proficiency must reach at least 6.5 of IELTS or equivalent (Li \& Tin 2013). Based on their past academic and cultural experience backgrounds are different from that of the tertiary education in (host country) Australian context as has administratively been set as the guideline for the core courses in every higher education (HE). One of the predominant background difference which likely becomes the constraint is pertaining to the academic life at tertiary level which is demanding a self-learning autonomy as the premise in order to enable students to cope with their academic pedagogical engagement which is mostly going on in a very fast and dynamic phase (Fielding and Stott, 2012, p. 2 as cited in (Xu \& Moloney 2014). Another different issue is due to the students' learning habitual style invested by the classroom instructional pedagogical engagement which tends to 
familiarize the students with the system of exam-based assessment orientation implemented in most of Asian country, including Indonesia (O'Donnell, 2005; Pritchard \& Maki, 2006 as cited in (Yanagi \& Baker 2015), rather than the system which is referring to the operation of the high level of thinking hierarchy to train them activate their thinking skills.

In this article I argue that attending such a challenging program is, nevertheless, expected to foster greater qualification in their field of teaching theories and pedagogy. This learning experience phase must equip them to be able to make changing and a big strand of progress, in particular, in the teaching of English for students learning TESOL program when going in their home country. It is, in turn, expected to diminish the poorness of Indonesian student achievements in English literacy at international arena, which is reported by the international assessment programs like Progress in International Reading Literacy Study (PIRLS) and Program for International Students Assessment (PISA) that they are even poorer than that of other Asian countries, such as Singapore and Malaysia and so forth, (OECD \& ABD, 2015, pp. 111-2).

\section{Method}

This research study is designed to answer the research questions of " how does the experience in learning TESOL at tertiary context in Australia impacts on the perception of Indonesian M. Ed students in English language learning and English language teaching in their home country context?. For the purpose, this research study is framed to be a descriptive qualitative analysis research design. This means that the data must be collected from the interviewees. As for the method used for collecting data as intended is semi-structure interview with opened ended questions as the instrument to note and to record their voices.

A semi-structured interview protocol was developed, in which most of the interview questions were open-ended in order to "allow the participants opportunities to develop their responses in ways which the interviewer might not have foreseen" Campbell, MC Namara, \&Gilroy, 2004, p.99). In order to avoid any potential ambiguous questions the interview questions were piloted in advance. As the researcher and participants were in Australia, the interviews were conducted in the ground flours of the University of Adelaide. Before the interviews, the participants were asked for their preference for the working language (i.e. English or Bahasa), and all the participants are Indonesian students who learning TESOL in the University of Adelaide.

The selected data were analyzed inductively into findings, which is involved organization of the information and categorization of coding. This process involved preparing and organizing the data, conducting a preliminary read-trough of interview texts, reducing the data into themes through a process of coding, and finally forming an interpretation from the data analysis (Creswell \& Clark, 2011, p. 179)

\section{Participants}

The participants of the research study who are involved in this study are the Indonesian M. Ed students who are studying at the school of Education Program, Faculty 
of Art at the University of Adelaide, South Australia for the commencement year of study 2015/2016. However, due to the amount of the students are quite a lot to conduct this research study with big population, the sample is, thus, demarcated to be eight participants only with the accounts: firstly, because of the time for holding this study is limited; secondly, because of the readiness and dependency of the participant candidates to participate voluntarily in is one of the accounts that cannot be intervened. So, although they have agreed with and been ready to attend for the interview event as the schedule and spots requested, several are fail to come and join the interview processes. In the light of it, the researcher is, nonetheless, able to interview eight participants from many candidates expected to be voluntarily participated. They are two women and six men and are students who register and study all core courses offered in Teaching of English as Speakers of other Language (TESOL) at Master of Education program, the University of Adelaide. Nevertheless, of all eight interviewees are successfully interviewed only four of them whose transcripts are analyzed as the representative transcripts of the samples. This is taken due to the limitation of the research time duration and the wide ranges of data are going to be exposed.

Table1. The details of participants

\begin{tabular}{|c|c|c|c|c|c|c|}
\hline Pseudonym & Age & Sex & $\begin{array}{c}\text { Years of } \\
\text { teaching at } \\
\text { any level }\end{array}$ & $\begin{array}{c}\text { Years of } \\
\text { graduate } \\
\text { from } \\
\text { Bachelor } \\
\end{array}$ & $\begin{array}{c}\text { Teaching } \\
\text { Recognition }\end{array}$ & $\begin{array}{c}\text { Years of } \\
\text { study at The } \\
\text { university of } \\
\text { Adelaide } \\
\end{array}$ \\
\hline Arjuna & 34 & Male & 6 year & 2007 & $\begin{array}{l}\text { Teaching English at } \\
\text { Nusring program }\end{array}$ & 2015 \\
\hline Bima & 25 & Male & $\begin{array}{l}\text { More than } \\
3 \text { year }\end{array}$ & 2014 & $\begin{array}{l}\text { Teaching English at } \\
\text { University, Junior and } \\
\text { senior high school }\end{array}$ & 2016 \\
\hline Sonia & 28 & Female & $\begin{array}{l}\text { More than } \\
3 \text { years }\end{array}$ & 2012 & $\begin{array}{l}\text { Teaching English at } \\
\text { University }\end{array}$ & 2015 \\
\hline Romi & 37 & Male & 16 years & 2000 & $\begin{array}{l}\text { Teaching English at } \\
\text { University }\end{array}$ & 2016 \\
\hline Angga & 26 & Male & $\begin{array}{l}\text { More than } \\
4 \text { years }\end{array}$ & 2012 & $\begin{array}{lr}\text { Teaching } & \text { BAHASA } \\
\text { for Australian student } \\
\text { in } \quad \text { Makassar } \\
\text { Indonesia. }\end{array}$ & 2015 \\
\hline Mawar & 25 & Female & $\begin{array}{l}\text { More than } \\
2 \text { years }\end{array}$ & 2014 & $\begin{array}{l}\text { Teaching English at } \\
\text { Senior High school }\end{array}$ & 2016 \\
\hline Bayu & 25 & Male & $\begin{array}{l}\text { More than } \\
2 \text { years }\end{array}$ & 2014 & $\begin{array}{lr}\text { Teaching } & \text { TOEFL in } \\
\text { English } & \text { Language } \\
\text { Course at } & \text { English } \\
\text { Village } & \text { Kediri } \\
\text { Indonesia } & \\
\end{array}$ & 2015 \\
\hline Doni & 30 & Male & 8 year & 2005 & $\begin{array}{l}\text { Teaching English at } \\
\text { Junior High school. }\end{array}$ & 2016 \\
\hline
\end{tabular}

\section{Discussion and Result}

Despite the data in the findings are mostly presented with more than one sample of participant data, in the discussion, the researcher may probably try to discuss and 
interpret one sample finding in each theme to simplify the flow of the discussion and to describe the qualitative value of phenomena, also because of the word limit span.

\section{English as interesting subject}

From the selected theme, the researcher can infer that there are few experiences in connection with the participant attractions of learning English when they were at school in Indonesia and while they are studying it at tertiary context in Australia.

"Yeach, this is only the subject that I like to learn about because I am pretty week to other subjects" (Shinta)

"Because, I am interested learning English since I was in Senior High School, when my teacher supported me to join English Club school. She was the first one person who inspired me to study English", (Mawar).

"Yeah, I enjoyed it I am interested in English since I was in Junior High School" (Arjuna)

Ultimately, it proves that they do not adore it because of the reason that English is a compulsory subject to learn at school in Indonesia, rather because they really like learning it as an interesting subject. Moreover, this is evidently supported by the other utterances when they are questioned other similar matter about whether or not they learn English out side of his normal English classroom learning engagement.

“...I attended English course for three months because what I learned at school was not cover all the things that required ..." (Arjuna)

Furthermore, they attraction for English do not stop only when they were in their country, Indonesia, but they also like it when they are learning TESOL in tertiary context in Australia.

"Yeah, I like studying TESOL ......", (Arjuna)

Interestingly, one of them, Arjuna's seriousness in learning English, A part from his TESOL classroom learning activities, he also attempts to learn and practice it outside the classroom from local people. For example, he takes part in certain voluntary social activities where a lot of local people are engaged in.

"At the first year of my semester I tried to adapt myself with the new environment and tried to join some clubs which most of the participant are Aussie or native speaker" (Arjuna)

From the information of the participants' experiences obtained in this theme, the researcher can drew few factors impact on the participants' perception in English language learning and English language teaching. They are feeling of confidence, awareness of developing skill, teachers' support and learning environment. All these factors are interrelated in a triadic reciprocal causation. In this conditional matter, the participants are attracted at learning English because of different stimulus or trigger, Arjuna because of his learning environment where stimulates his feeling of conflict of interest at the beginning. Through his cognition process, he behaves to change or to shape the new environment to learn English when many do not seemingly like it 
"Yeach, this is only the subject that I like to learn about because I am pretty week to other subjects" (Shinta). The same case as happen to other participant, Mawar. The difference is that she is stimulated by an external stimulus from her teachers' support to behave on her target.

\section{The important role of teachers}

This theme sounds familiar, in particular in the field of education. It is because one of the fundamental factors determines the student engagement in learning and achieving their learning goals is teachers. Nevertheless, the researcher is not influenced by the obsessive notion. The theme is determined to be one of major themes, since many participants voice such theme in the whole of their interview data. Here is one of the sample transcripts, when the interviewer (researcher) asks one of the interviewees, Mawar about her reason why she feels interested at learning English, she responds that her teacher was the first person who inspires her not other people, neither her parents.

"Because, I am interested learning English, since I was in Senior High School, when my teacher supported me to join English Club school. She was the first one person who inspired me to study English", (Mawar).

Another account that strengthens the selection of the theme is not merely because the single answer of Mawar's as stated in the quotation, rather because her other comments responding to the question "what should your English teacher do to improve his/her teaching?"

"I think they have to have been learning activities which are more fun and not boring. They used to teach students in such monotonous way, like writing materials on blackboards, then asked students to do the exercises in books (like student working sheet) then check the answer and done", (Mawar).

Her narration indicates that Mawar's previous English teachers were most likely categorized as those who were practicing traditional teaching method with teacher center learning focuses rather than its opposition. However, from the information obtained from the interviewee, researcher can argue that the important point can be learned is that the role of teacher can be powerful and holistic. Even, based on the narration, they were not in their perfect professional performance in practicing their role as the ideal teachers, they are still be accounted by their students. It can be confronted with the previous sample response of Mawar. This evidence is strong enough, because when she expresses that she was inspired by her English teachers to learn the subject years ago. They were her ex-teachers already. If she wants, she could underestimate them. What's more she confesses that she has been learning more new methods and etc in tertiary education in Australia.

“... I learn a lot about how to teach English well” (Mawar).

From this theme, the researcher can drew at least three major factors which impact on the participants' perception in learning and teaching English in their home country. They are teachers' support, intrinsic value and culture norm. 
These three factors influence each other. Begin first from teachers' support to Mawar, then, with her internal value via intervening cognition, she behaves to learn English. However because of the other external factor, cultural norm, so that although she realizes her previous teachers were likely more traditional in teaching, she does not need to change his behavior to disrespect on them. Instead of suggests them to alter their ways of teaching more progressively after her new environment where she learn English in Australia, has helps her to be knowledgeable in recognizing more methodology, teaching pedagogic practices and the way of theorizing her concepts with regard to her practices in teaching.

\section{The need for teacher's corrective reflection}

This theme is ultimately contradictive with the previous theme. However, apart from its contradictive, a number of participant express their voices on it. One of the narrative responses from the interviewees, when he is asked the question pertaining to TESOL learning experience "How much do you enjoy your classroom activities?",

"I am not really enjoyed it. ...... actually I have a high expectation of the TESOL that I will learn. For example, in the language and culture class, ..." (Bayu)

It is obvious that there are two contradictive sentences. The first sentence can likely be interpreted to negate his effort for learning TESOL, while the second one can be likely interpreted to expect it highly. From the sentences can be inferred that there is a gap that need to answer. Hence, the researcher tries to expose more interviewee's responses to help us to weave the missing information.

For the intention, the interviewer continues asking "Why?", the respondent answers:

"For example, in the language and culture class, the lecturer actually from Asian but because she was growing up in Australian, so I think her English is very fluent. But the methods or the technique she used is not really good. I also think that the content of the course is not related to the title of it ". (Shinta)

This narration confirms and supports the sound evidence from many theories, one of which is as hold in the discussion in the previous chapter of this research study that if a teacher wants to assist his or her students to learn, no other way, except recognize and understand them holistically (Devlin et al, 2012, p. 4). Furthermore, the students are inclusive and their characters, culture, educational, learning style background to mention few are seriously distinctive as narrated by the respondent.

".... She also not realized that she is teaching the students from multicultural background, so she speaks too fast. Another thing still regarding to TESOL, for me she can be a good model for us who will be a teacher. According to me being a teacher, we should also be aware of students' social background, so we can use different approach to engage them in the class". (Shinta)

This theme is thus reasonable to expose to be aware of for corrective reflection. Not for falsifying any one teacher, staff or institution, but for the development of quality services in education, specifically international students, from Indonesia. 
From this theme, the researcher can highlight teacher's teaching performance, conflicting interests and self-expectation. This three factors impact on the participant's perception. Through the participant experiences, she witnesses teachers' teaching performances in the classroom. When in this experiential learning situation, the participant encounters a contradictive performance of the teacher which is different from the ideal one as expected by the participant. It can raise new conflict of interest between teachers and students to act for change or shape the condition or not. Unsolved condition will lower the participants' expectation that in turn deficits self-confidence and learning outcome.

\section{The benefits of peer and group learning discussion}

This theme is also selected to be one of the five themes, since the many participants are expressing their insights in conjunction with peer and cooperative learning phenomena. The interviewees admit that they feel like learning much and taking more benefits from learning, either with their peer or group discussion. Here are two sample narrations:

“...I can learn from other students who learn English as not their own language", (Mawar)

From the narration, it can be read clearly that the participant, Mawar can learn from other friends in the form of group discussion and the like and, of course, she can obtain more benefits from her learning as she expresses in her sentences below.

“... I practice my speaking with them, like when I talk with Australian, I can learn a lot of new vocabulary that I ever used before". (Mawar) "The group discussion for example, it is really helpful to improve my English, at least I can practice to communicate with my friends, especially with those who come from different countries". (Mawar).

The process of taking benefit from peer learning is also emphasized by the confession of the other participant who even enthusiastically expresses one of his classmates feeling with regard to peer learning as narrated below.

"And one of my friend who is native, she said that she can learn more from friend rather than from the lecturer. She said I got nothing from lecturer but many things from you mates". (Shinta)

This expression indicates that his classmate is also interested to learn from others, including him. Conversely, one of the following participant also expresses that he can learn from his other friends including the technique how to teach.

“... I learn many things here and I got many experience from my friends from another countries or who have different teaching background experience. So I learn much from them, which I think will really help me when I come back home. I will implement what I have learned here... ". (Arjuna)

One thing needs to bear in mind with peer learning or group learning discussion is to avoid the group which engages homogeneous background, especially for English learning group, because it can impede learning process. This is including in grouping the students from the same country of origin.

"It is not to useful when the teacher asks us to be in a group from the same country background since we feel more comfort to speak in our own language whenever we sit 
together. It's a bit helpful when we are in different background and I found it best if there is Australian student in the group". (Shinta)

From the narration of the participant, it is apparent that learning will be worthwhile for learning engagement when the group is heterogeneous and in term of learning language will be more beneficial if in the group is involved the local Australians.

In this theme, the factors that will be highlighted are peers, cultural norm and mediated learning experience. In term of learning, peer or group learning is contributive for learning. To behave on the process of adaptation for learning, this should be mediated in the arena of experiential learning such as peer learning and group learning discussion. Nevertheless, the cultural norm of each member will become obstacles to behave, so that the participative, constructive decision for mediation will enable the thinking process for generating way to behave upon target plan. This will in turn will benefits learners' language learning.

\section{Student Preference for NESTs}

The controversial debate regarding with the issue whether NESTs or NNSTs are appropriate, efficient and effective to teach English or not are still going on and there is no final decisive finding yet. Nevertheless, the majority of participants of the interview come up with the theme as one of the five major themes extracted from their interview transcript data.

"I think I prefer native to non-native. Because, I need to learn from them directly so it can help me to improve my pronunciation and I can speak like foreigner. Beside that we can also learn about their culture of the language, for example we can learn what word which is polite and impolite from the native English teacher". (Bima)

From the narration, we can see and read what and why the participant chose NESTs. The reason NESTs is selected is to enable them to learn more, namely to improve the participant's pronunciation, culture of the native people through their language and the contextual use of words.

"I prefer learning from native, because sometimes the meaning of words is not only about the literal meaning, but it is a context dependent meaning. For example, we have to learn idioms in order to understand its underlying meanings. We cannot gain such kind of this experience if just learn English from those who are non-natives". (Arjuna)

This narration indicates that the other participant also select NESTs rather than NNESTs. His reason for selecting NESTs is rather identical to the previous participant that is to be able to learn the contextual meaning of the English words.

There are only a number of participants do not express their precise preference exactly. This is as exemplified by one of the participant below.

"It depends, as long as they can encourage me or as long as what they teach is understandable, that is no matter for me. From native we can learn a lot of things such as dialect, pronunciation, and also the way they speak..”. (Mawar)

From the narration, we can understand that the participant is a bit hesitated to chose, although she understands the benefit of being taught by the NESTs. 
In the top of it, the factors that can be drawn from the theme are target language, Local education system and societal expectation. Based on the data exposed, it is evident that the majority of participants prefer NESTs to NNESTs. This decision of them is most likely motivated the fact that the desire to optimize their achievement in the target language has motivated the participant to learn their English from NEST. This may be because of societal expectation where they come from, because they will come back to practice to the society who expect them much. Nonetheless, few of the participants admit that their English do not get significant improvement. This is probably because of the local education system may render their behavior to maximize their learning from NESTs' fully, because the system has been set proportionally. For example, based on the system implied student should be learning autonomously. Thus, if for instance, the participants want to get more time allocation for learning from NESTs as they experience learning in their home, they need to change or to shape another new environment of learning through further stimulus or negotiable behaviors. It is including the possibility to behave for changing or shaping the new environment when by chance their teacher is NNESTs and experience something which is not as their expectation as the sample from one of the participant's narration below.

However, regarding the issue, the latest participant is may be interesting to highlight, since the participant's response sounds so serious regarding NNESTs.

“... actually I have a high expectation of the TESOL that I will learn. For example, in the language and culture class, the lecturer actually from Asian, but because she was growing up in Australian, so I think her English is very fluent. But the methods or the technique she used is not really good. I also think that the content of the course is not related to the title of it ". (Shinta)

\section{Conclusion and Suggestion}

\section{Conclusion}

Despite from the broad presentation and discussion in the chapter of finding, discussion and interpretation, there are still many more factors can likely become the prevalence determining the way how the experience in learning TESOL in tertiary context in Australia impacts on the Indonesian students' perception in English language learning and English language teaching, this research study have, however, come up with some points of conclusion.

Firstly, based on the data in the theme' The students' attraction for English, the participants' perception in learning TESOL is impacted by the feeling of confidence, awareness of developing skill, teachers' supports and learning environment, by way of encountering the combination of these factors which are processed in the triadic reciprocal causation. This process generates the students' learning behavior for English. Secondly, in the theme 'the important role of teachers' the participants' perception can be impacted by the factors: teachers' support, intrinsic value and culture norm. The teachers' support is given to the participant through the participant internal value via cognition process, she get stimulus to behave on learning English. The local cultural norm (external determinant) belong to the participant controls over the later consequence of knowing that her teachers traditional model of teachers. 
Thirdly, the teacher's teaching performance, conflicting interests and self-expectation are the factors that can be drawn from the theme 'the need for teachers' corrective reflection'. These three factors can be the determinant factors with regard to the theme, the unbalance of any determinant causality can impacts on their perception in learning. Fourthly, peers, cultural norm and mediated learning experience are the other factors impacting on student learning TESOL. In term of learning, peer or group learning is contributive for learning. To behave on the process of adaptation for learning, this should be mediated to activate and fascinate learning engagement. Otherwise, this can impact on their perception for learning. And the fifth, the factors that are drawn from the theme of 'students' preference for NESTs are target language, Local education system and societal expectation. The eagerness for study TESOL as target language can raise one of which because of societal expectation. However, due to local education system which likely different from their culture of learning, for instance self-learning (autonomy), it can impact on their perception in learning.

\section{Suggestions}

Referring to the conclusion above, the researcher can argue that learning about perception is necessary to commit because by that ways, students' way of thinking, insight, believe about what is going on in the real world can be exposed to be something meaningful to learn. It is necessary, since the world is sometimes complicated, including when students attend to classroom for learning TESOL, moreover the inclusiveness of students are not seriously detected or acknowledged.

This study is still limited meaning that there are still many factors that are not yet covered in this study, for example, with regards to the difference between female and male in the way how their perception may likely be impacted by their experience and etc. It is, therefore, the coming students are expected to look into this study to discern other possible aspects that are absent from the researchers' attention for the improvement of this study and in particular the development of science and technology specifically in education. 


\section{References}

Anderman, EM \& Patrick, H 2012, 'Achievement goal theory, conceptualization of ability/intelligence, and classroom climate', Handbook of research on student engagement, Springer, pp. 173-191.

Andrade, MS 2006, 'International students in English-speaking universities adjustment factors', Journal of Research in International Education, vol. 5, no. 2, pp. 131-154.

Barnes, BD \& Lock, G 2013, 'Student Perceptions of Effective Foreign Language Teachers: A Quantitative Investigation from a Korean University', Australian Journal of Teacher Education, vol. 38, no. 2, p. n2.

Burke, BM 2007, 'Creating communicative classrooms with experiential design', Foreign Language Annals, vol. 40, no. 3, pp. 441-462.

Burnard, P 1991, 'A method of analysing interview transcripts in qualitative research', Nurse education today, vol. 11, no. 6, pp. 461-466.

Campbell, JD, Trapnell, PD, Heine, SJ, Katz, IM, Lavallee, LF \& Lehman, DR 1996, 'Selfconcept clarity: Measurement, personality correlates, and cultural boundaries', Journal of personality and social psychology, vol. 70, no. 1, p. 141.

Canale, M \& Swain, M 1980, 'Theoretical bases of com-municative approaches to second language teaching and testing', Applied linguistics, vol. 1, no. 1, pp. 1-47.

Carrasquillo, AL 2013, Teaching English as a second language: A resource guide, Routledge.

Collins, L \& Angelova, M 2015, 'What Helps TESOL Methods Students Learn: Using Q Methodology to Investigate Students' Views of a Graduate TESOL Methods Class', International Journal of Teaching and Learning in Higher Education, vol. 27, no. 2, pp. 247260.

Ellis, R 1982, 'Informal and formal approaches to communicative language teaching', ELT journal, vol. 36, no. 2, pp. 73-81.

Elo, S, Kääriäinen, M, Kanste, O, Pölkki, T, Utriainen, K \& Kyngäs, H 2014, 'Qualitative content analysis', Sage Open, vol. 4, no. 1, p. 2158244014522633.

Engler, B 2013, Personality theories, Nelson Education.

Harmer, J 1998, How to teach English: An introduction to the practice of English language teaching, Longman.

_ 2012, Essential teacher knowledge, Pearson Longman.

Horwitz, EK 1988, 'The beliefs about language learning of beginning university foreign language students', The Modern Language Journal, vol. 72, no. 3, pp. 283-294.

Howatt, APR \& Widdowson, HG 2004, A history of ELT, Oxford University Press. 
Jalal, F \& Sardjunani, N 2006, 'Increasing literacy in Indonesia', Adult Education and Development, vol. 67, p. 131.

Jang, H, Reeve, J, Ryan, RM \& Kim, A 2009, 'Can self-determination theory explain what underlies the productive, satisfying learning experiences of collectivistically oriented Korean students?', Journal of Educational Psychology, vol. 101, no. 3, p. 644.

Jeannin, L 2013, 'Students' Perception of Diversity in an International Classroom', Higher Learning Research Communications, vol. 3, no. 4, p. 6.

Kachru, BB 1992, The other tongue: English across cultures, University of Illinois Press.

Kenny, B \& Savage, W 1997, Language and development: Teachers in a changing world, Longman Pub Group.

Kervin, L \& Mantei, J 2016, 'Assessing Emergent Readers' Knowledge About Online Reading', The Reading Teacher, vol. 69, no. 6, pp. 647-651.

Larsen-Freeman, D \& Anderson, M 2013, Techniques and Principles in Language Teaching 3rd edition, Oxford university press.

Lessow-Hurley, J 2003, Meeting the needs of second language learners: An educator's guide, ASCD.

Lewis, M \& Hill, J 1992, Practical techniques for language teaching, Language teaching publications Hove,, England.

Li, B \& Tin, TB 2013, 'Exploring the expectations and perceptions of non-native English speaking students in masters level TESOL programs', New Zealand Studies in Applied Linguistics, vol. 19, no. 2, p. 21.

Lightbown, PM, Spada, N, Ranta, L \& Rand, J 1993, How languages are learned, vol. 998, Oxford University Press Oxford.

Loewen, S \& Reinders, H 2011, Key concepts in second language acquisition, Palgrave Macmillan.

Mahmud, S \& Bretag, T 2013, 'Postgraduate research students and academic integrity: 'It's about good research training", Journal of Higher Education Policy and Management, vol. 35, no. 4, pp. 432-443.

Matsumoto, M 2009, 'Second language learners' motivation and their perceptions of teachers' motivation'.

Morris, DB \& Usher, EL 2011, 'Developing teaching self-efficacy in research institutions: A study of award-winning professors', Contemporary Educational Psychology, vol. 36, no. 3, pp. 232-245.

Murray, DE \& Christison, M 2010a, What English language teachers need to know II: facilitating learning, Routledge. 
2010b, 'What English language teachers need to know: understanding learning, Vol 1'.

Musthafa, B 2001, 'Communicative Language Teaching in Indonesia: Issues of Theoretical Assumptions and Challenges in the Classroom Practice'.

Phakiti, A, Hirsh, D \& Woodrow, L 2013, 'It's not only English: Effects of other individual factors on English language learning and academic learning of ESL international students in Australia', Journal of Research in International Education, vol. 12, no. 3, pp. 239-258.

Phakiti, A \& Li, L 2011, 'General academic difficulties and reading and writing difficulties among Asian ESL postgraduate students in TESOL at an Australian university', RELC Journal, vol. 42, no. 3, pp. 227-264.

Ramachandran, NT 2011, 'Enhancing international students' experiences: An imperative agenda for universities in the UK', Journal of Research in International Education, vol. 10, no. 2 , pp. 201-220.

Reszke, SM 2011, 'Training and transitions: The lived experiences of adult learners of English as a Second (or Other) Language', University of Tasmania.

Richards, JC \& Rodgers, TS 2014, Approaches and methods in language teaching, Cambridge university press.

Ryan, RM \& Deci, EL 2000, 'Self-determination theory and the facilitation of intrinsic motivation, social development, and well-being', American psychologist, vol. 55, no. 1, p. 68.

Sadtono, E 1976, 'Problems and progress in teaching English as a foreign language in Indonesia", Sixth World Congress of the International Reading Association (17-19 August) in Singapore.

Samra-Fredericks, D 2003, 'Strategizing as lived experience and strategists' everyday efforts to shape strategic direction', Journal of management studies, vol. 40, no. 1, pp. 141-174.

Savignon, SJ 2007, 'Beyond communicative language teaching: What's ahead?', Journal of Pragmatics, vol. 39, no. 1, pp. 207-220.

Sawir, E, Marginson, S, Deumert, A, Nyland, C \& Ramia, G 2008, 'Loneliness and international students: An Australian study', Journal of Studies in international Education, vol. 12 , no. 2, pp. 148-180.

Schunk, DH \& Mullen, CA 2013, 'Toward a conceptual model of mentoring research: Integration with self-regulated learning', Educational Psychology Review, vol. 25, no. 3, pp. 361-389.

Sherman, RR \& Webb, RB 1988, Qualitative research in education: Focus and methods, vol. 3, Psychology Press.

Slavin, RE \& Davis, N 2006, 'Educational psychology: Theory and practice'. 
Sugiharto, S 2014, 'Disentangling Linguistic Imperialism in English Language Education', The Routledge Handbook of Educational Linguistics, p. 224.

Trent, WT \& John, EPS 2008, Resources, assets, and strengths among successful diverse students: Understanding the contributions of the Gates Millennium Scholars Program, vol. 23, Ams PressInc.

Wentzel, KR 2009, 'Peers and academic functioning at school'.

Xu, HL \& Moloney, R 2014, 'Identifying Chinese heritage learners' motivations, learning needs and learning goals: A case study of a cohort of heritage learners in an Australian university', Language Learning in Higher Education, vol. 4, no. 2, pp. 365-393.

Yanagi, M \& Baker, AA 2015, 'Challenges Experienced by Japanese Students With Oral Communication Skills in Australian Universities', TESOL Journal.

OECD/Asian Development Bank. (2015). Education in Indonesia: Rising to the Challenge. Paris: OECD Publishing. Retrieved from http://dx.doi.org/10.1787/9789264230750-en

\section{APPENDIX}

\section{Interview questions sheet}

1. Background information

2. How long have you been learning English?

3. When were you attending your class at school as a child, how much was English used as instruction by the teacher?

4. Did you like your English's way of teaching at school?

5. How do you think it could be improved?

6. Have you attended additional studies in English language outside of school or since you have left school?

7. Were you required to meet a minimum score for IELTS, TOEFL or other test to be accepted into tertiary education in Australian?

8. Were you satisfied with your score?

9. How long did you prepare for the test?

10. Do you like study TESOL?

11. Were your teacher native or non-native English background?

12. Whilst attending your master's studies in Adelaide, do you study and practice English outside of your classroom activities?

13. How much do you enjoy your English classroom learning activities? Why?

14. Do you prefer learning English from a native or non-native English speaker? Why?

15. How do you compare your English learning activities and your English teaching theory, pedagogy and practice experience that you got from the lecturer since you study in Adelaide compare to what to what you have done in your home country?

16. Do you think your English classroom activities help you develop your English mastery?

17. Have you been teaching English? 
18. What level are you teaching?

19. Can you describe your teaching style?

20. Do you think your TESOL learning activities help you develop your ability to teach English language in Indonesian context?

21. Do you think studying in Adelaide has helped you to improve your English mastery and your future English practices? How? 